\title{
Socio-environmental Impacts Associated with Burning Alternative Fuels in Clinker Kilns
}

\author{
Luciane P. C. Monteiro \\ Escola de Engenharia \\ Universidade Federal Fluminense \\ Niterói, Rio de Janeiro, Brazil \\ luciane@predialnet.com.br
}

\author{
Fernando B. Mainier \\ Escola de Engenharia \\ Universidade Federal Fluminense \\ Niterói, Rio de Janeiro, Brazil \\ fmainier@uol.com.br
}

\author{
Renata J. Mainier \\ Prog. Pós-Graduação Eng.Civil \\ Universidade Federal Fluminense \\ Niterói, Rio de Janeiro, Brazil \\ renatajogaibmainier@msn.com
}

\begin{abstract}
The pollutants found in emissions from cement plants depend on the processes used and the operation of the clinker kilns. Another crucial aspect concerns the characteristics of raw materials and fuels. The intensive use of fuels in rotary kilns of cement plants and the increasing fuel diversification, including fuels derived from coal and oil, from a multitude of industrial waste and from biomass, charcoal and agricultural waste (sugarcane bagasse, rice husk), is increasing the possibilities of combinations or mixtures of different fuels, known as blends. Thus, there are socio-environmental impacts associated with the burning of alternative fuels in clinker kilns. In view of the growing trend of entrepreneurs who want to target the waste produced in their unit and of the owners of the cement plants who want to reduce their production costs by burning a waste with lower cost than conventional fuels, it is necessary to warn that a minimum level of environmental care should be followed regarding these decisions. It is necessary to monitor the points of emission from cement kilns and in the wider area influenced by the plant, in order to improve environmental quality. Laboratory studies of burning vulcanised rubber contaminated with arsenic simulate the burning of used tyres in cement clinker kilns producing $\mathrm{SO}_{2}$ and $\mathrm{As}_{2} \mathrm{O}_{3}$.
\end{abstract}

Keywords- cement plants; arsenic; tyres; clinker kilns

\section{INTRODUCTION}

Co-incineration of waste in industrial clinker kilns is a practice that dates back to the time of the oil crisis and is currently being viewed as a coordinated action among industries and cement industries that generate waste, more contextualised in the environmental sphere and less in the energy sphere and considered by waste generators with the approval of environmental agencies, as a final solution for the disposal of their industrial waste.

It should also be noted that in the manufacture of cement, as in any other large industrial activity, risks are associated with the scale of operations, i.e., they depend on the quantities of waste handled, transported, prepared, fed and incinerated and the degree of dangerousness of such materials. Therefore, the scale of the enterprise determines the extent of risk exposure for workers, the surrounding population and the environment.
The most commonly used cement is composed of $96 \%$ clinker and 4\% gypsum by mass. The clinker is produced from the thermal treatment in rotary kilns at elevated temperatures of a rocky material usually containing $80 \%$ calcium carbonate $\left(\mathrm{CaCO}_{3}\right), 15 \%$ silicon dioxide $\left(\mathrm{SiO}_{2}\right), 3 \%$ aluminium oxide $\left(\mathrm{Al}_{2} \mathrm{O}_{3}\right)$ and minor amounts of other constituents, such as iron, sulphur and others. These materials are found in limestone deposits often located near the site of the clinker kiln. The raw material is mixed and finely ground, before being subjected to a heating process that leads to the production of clinker $[1,2]$.

The minerals employed as raw materials for cement might be associated with a number of other secondary minerals, which might contain other contaminants in the form of complex salts or oxides. Other dangerous contaminants to be highlighted include lead, copper, zinc, thallium, cadmium, chromium, nickel and arsenic. Additionally, if burning chlorinated compounds, then fluoride and sulphide minerals might lead to problems of equipment corrosion and serious socio-environmental problems.

\section{RISKS AND CONTITIONS FOR CO-PROCESSING INDUSTRIAL WASTE}

For the daily processing of 3600 tons of clinker, the main component of the cement kiln, a large capacity, an oil-fired rotary kiln is required, which would consume about 300 tons of fuel, or the equivalent of ten tanker truck loads.

In Brazil, the number of operating cement plants is 487 and among those, 30 have environmental licences for co-processing waste, consuming the equivalent of $39.48 \%$ of the total energy consumption of the country $[3,4]$.

Around 1979-1981, the price of fuel oil tripled because of the national dependence on imported oil. A scheme was then introduced where the supply of fuel oil for industries, should not exceeding the consumption practiced in 1979.

Thus, incentives and subsidies were introduced for some alternative sources of fuel and heat energy, through the signing of protocols for the use of domestic coal for the steel, cement, paper and cellulose industries.

In September 1979, the cement industry signed the "Protocol Reduction and Replacement Fuel Oil Consumption 
in Cement Industry", which pledged to achieve by the end of 1984, the total substitution of fuel oil consumed by cement plants in their domestic production and to adopt energy conservation measures at the plant level. Thus, in 1985, the cement industry had already replaced about $95 \%$ of its fuel oil consumption $[3,5]$.

According to Ferrari [6], the basic assumptions for the use of waste in clinker kilns are:

- not all types of waste may be used in cement clinker kilns owing to environmental restrictions (legislation) and to the manufacturing process of clinker

- checking of the residue using partial replacement for fuel and/or as partial replacement of raw materials

- the consideration that a residue might be considered as fuel and must provide heat to the process

- if the residual considered for a partial replacement of the raw material should contain as major components: calcium, silicon, aluminium and iron. Included in this case are material mineralisation and/or fluxes

- $\quad$ assessment of physico-chemical characteristics. Certain contaminants from waste should be in limited amounts in relation to the feeding rate of waste to the furnace

- the maximum rate of feeding the waste to the clinker kiln is established by material balances, based on previous tests

\section{A. Principal characteristics of the clinker kiln}

The clinker kiln should be adequate for the incineration of diverse industrial waste [6]. For example:

- $\quad$ The oven must be able to operate at high temperatures, which is needed for the destruction of some hazardous organic wastes. The material in the kiln for production of cement clinker, must reach temperatures of 1400 $1500{ }^{\circ} \mathrm{C}$ and the heating of the material requires a flame temperature of $3200{ }^{\circ} \mathrm{C}$. The residence time at temperatures above $1100^{\circ} \mathrm{C}$ is 6 to 10 seconds.

- The need for turbulent gases in the furnace system with a Reynolds number greater than 100,000; a condition that is highly favourable for the process of combustion and destruction of waste.

- The clinker kiln has a basic environment that neutralises acid gases by the very nature of its raw materials.

- The complete elimination of waste is expected, because the ash produced by incineration of residues is incorporated in the mass of the clinker produced.

- $\quad$ Stopping the waste stream following any mishap in relation to normal conditions of operation.

The clinker kilns are necessarily a function of the basic relationship between the amounts of $\mathrm{CaO}$ (calcium oxide) and $\mathrm{SiO}_{2}$. Thus, the $\mathrm{CaO} / \mathrm{SiO}_{2}$ ratio must be greater than one, i.e.,
$\mathrm{CaO}$ must be present in greater quantity than $\mathrm{SiO}_{2}$, characterising the basics of the furnace system [6].

\section{B. Operations in cement plant licensed for the burning of industrial waste}

The cement manufacturing operation with residues using alternative fuels are based on two steps.

\section{1) Step 1: Preparation and conditioning of waste fuel}

This step involves the following operations: receiving the waste, temporary storage, classification, segregation, mixing of different sources to form a blend with acceptable calorific value and finally, packaging in standard.

\section{2) Step 2: The co-processing}

This stage involves the following operations: overflow system, raising and feeding of waste packaged in patterns; system storage, mixing and transport of solid waste; storage system, pumping, transporting and injecting viscous mixture of waste; storage system, pumping, transportation and injection of liquid waste mixture.

\section{MONITORING THE OPERATION OF A CEMENT UNIT IN RELATION TO ENVIRONMENTAL CONTAMINATION}

The environmental monitoring of a cement unit should be done by the industry and their records made available to the environmental control agencies based on the following guidelines. There should be periodic and non-periodic monitoring of parameters according to the composition of the waste that is fed to the furnace and among the sampling points critical to the control, such as:

- $\quad$ Sampling and analysis of the flue gases

- Sampling and analysis of clinker produced

- Reporting and documentation requirements of the environmental agency second controller

- Monitoring of air quality in the vicinity of the plant

- Control of the final specification of the cement produced when using industrial waste in the clinker furnace

Continuous monitoring is done by analysing and recording one or more parameters whenever the facility is in operation. In the furnace fuel particulate material, $\mathrm{SO}_{\mathrm{x}}, \mathrm{NO}_{\mathrm{x}}, \mathrm{CO}$ and $\mathrm{CO}_{2}$ are monitored. Periodic monitoring is performed by analysing and recording particulate materials, $\mathrm{SO}_{\mathrm{x}}, \mathrm{NO}_{\mathrm{x}}$, fluoride, chlorine, metals, cyanides, POPs (persistent organic compound) and VOCs (volatile organic compounds). One has to consider the inclusion of a label stating that the cement being used was produced from the burning/co-incineration of waste, as well as an identification of the main types of contaminants expected in the product [7-9]. 


\section{RISKS RELATED TO WORKERS' HEALTH, PUBLIC HEALTH AND THE ENVIRONMENT}

Risks in the field of cement production are present in the form of occupational accidents with the introduction of industrial waste of any nature, which could cause immediate, acute toxicity to the workers following a break in the reliability of the process, irrespective of whether or not alternative fuels are used in the clinker furnace.

As other forms of occupational risks, the cement units might impart a progressive chemical contamination to their workers that manifests over time. Another risk related to cement production, concerns the character of environmental contaminants transferred, for example, through some climatic factor (wind and/or rain) to surrounding neighbourhoods and industrial units. There are risks related to the use of waste in cement from its place of origin to the final cement production involving all who participate in this operation.

The characteristics of the technological process and the physico-chemical and toxicological properties of the raw materials and inputs employed in cement production, mean that cement plants pose risks to workers' health, public health and to the environment. These are mainly associated with exposure to the material in powder form that permeates the entire chain of production and from emissions of polluting substances, which occur continuously and even in small concentrations, characterise a chronic risk [1].

Therefore, the entire cycle of the cement manufacturing process constitutes risk; the mining and processing of lime, the grinding and homogenisation of raw materials, the manufacture of clinker and the grinding and dispatch of the cement.

Throughout this process, there are emissions of particulate matter, consisting of the raw materials, clinker and cement, salt vapours, metal and gases formed in the combustion process and other missions generated elsewhere in the plant. The risk of further dissemination remains when using the cement end product. Table I presents some metals found in solid waste and their consequences to human health.

TABLE I. METALS Vs RISKS

\begin{tabular}{|l|l|l|}
\hline Contaminant & \multicolumn{1}{|c|}{ Solid Waste } & \multicolumn{1}{c|}{ Disease } \\
\hline Cadmium & $\begin{array}{l}\text { Solder, tobacco, batteries } \\
\text { and cells. }\end{array}$ & $\begin{array}{l}\text { Lung and prostate } \\
\text { cancer, kidney injury. }\end{array}$ \\
\hline Chromium & $\begin{array}{l}\text { Industrial dyes, enamels, } \\
\text { paints, steel and nickel } \\
\text { alloys. }\end{array}$ & $\begin{array}{l}\text { Asthma (bronchitis), } \\
\text { cancer. }\end{array}$ \\
\hline Nickel & $\begin{array}{l}\text { Nickel-cadmium batteries, } \\
\text { nickel electrowinning, } \\
\text { castings. }\end{array}$ & $\begin{array}{l}\text { Breast and lung cancer, } \\
\text { sinuses. }\end{array}$ \\
\hline
\end{tabular}

\section{LABORATORY TESTING BURNING OF VULCANISED} RUBBER CONTAINING ARSENIC

The incineration of industrial residues in rotary kilns has been discussed across the world, because of the environmental problems caused to the atmosphere and the quality of the produced cement. This affects the sustainability of the cement industry because it has to guarantee the raw materials and fuels, as well as obey the environmental legislation. Used tyres containing toxic contaminants are an example of this kind of fuel [11].

This experimental phase of the study was to simulate the burning of scrap tyres in cement clinker kilns generating gaseous environmental contaminants, such as arsenious oxide $\left(\mathrm{As}_{2} \mathrm{O}_{3}\right)$ and sulphur dioxide $\left(\mathrm{SO}_{2}\right)$.

The experimental method consisted of the preparation of rubber coupons (styrene-butadiene) with sulphur vulcanised to a high purity and contaminated with arsenic and sulphur. About $100 \mathrm{mg}$ of finely grated coupons was placed in a porcelain crucible and subjected to firing at $1000{ }^{\circ} \mathrm{C}$ in a furnace with a controlled temperature heating rate $\left(10{ }^{\circ} \mathrm{C} / \mathrm{min}\right)$ and an atmosphere of helium and oxygen at a flow rate of $30 \mathrm{~cm}^{3} / \mathrm{min}$, as shown in Figure 1.

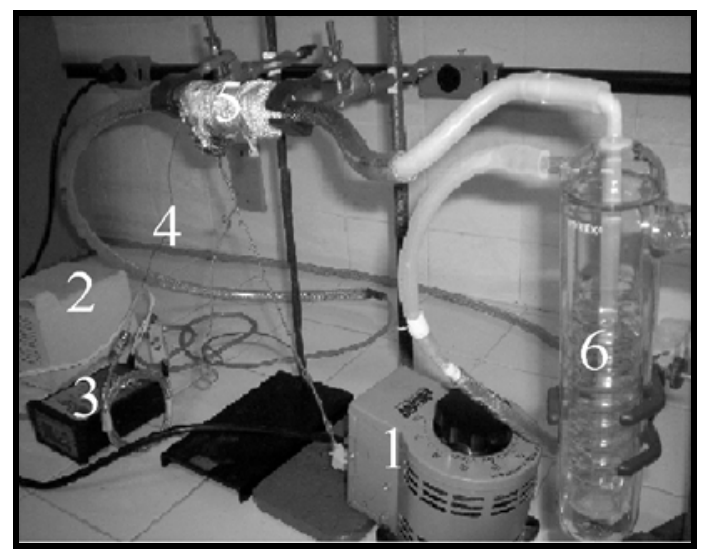

Fig. 1. Equipment used for burning of rubber shavings: 1-voltage regulator, 2-nebuliser, 3-temperature indicator, 4-thermocouple, 5-heating mantle, 6-bottle containing sodium hydroxide solution

The combustion gases were collected in a flask with a $2 \mathrm{M}$ sodium hydroxide solution. The results of the burning of the rubber contaminated with sulphur and arsenic are shown in Table II.

TABLE II. BURNING OF THE RUBBER CONTAMINATED WITH SULPHUL AND ARSENIC

\begin{tabular}{|c|c|c|c|c|}
\hline \multirow{2}{*}{ Samples } & \multirow{2}{*}{$\begin{array}{c}\text { \% sulphur } \\
\text { in rubber }\end{array}$} & \multirow{2}{*}{$\begin{array}{c}\text { \% } \\
\text { arsenic in } \\
\text { rubber }\end{array}$} & $\begin{array}{c}\text { GO2 } \\
\text { mg/L }\end{array}$ & $\begin{array}{c}\text { As2O3 } \\
\text { mg/L }\end{array}$ \\
\hline 1 & 11.13 & ----- & 1510 & \\
\hline 2 & 14.45 & ----- & 17450 & \\
\hline 3 & 11.13 & 4.46 & 1600 & 158 \\
\hline 4 & 14.45 & 4.46 & 1570 & 164 \\
\hline 5 & 14.45 & 16.65 & 17600 & 740 \\
\hline
\end{tabular}

\section{CONCLUSIONS}

Based on the study, the following conclusions are considered as critical:

- the majority of workers in the cement industry, as well as the residents in the neighbourhood of these factories are unaware of the origins and contents of waste fuels that are burned in the clinker ovens 
- usually waste chemicals from various segments are mixed with sawdust to form a mixture based on economic value and with a calorific value viable for burning

- $\quad$ there are no effective controls placed on the burning process and equipment used by the cement factories nor on the toxic gaseous contaminants generated during the burning process

- laboratory analyses carried out on burning vulcanised rubber coupons contaminated with arsenic, simulating the burning of used tyres, generated significant levels of arsenic oxide $\left(\mathrm{As}_{2} \mathrm{O}_{3}\right)$

- burning of scrap tyres in clinker kilns is not a recommended alternative for the disposal of this environmentally troublesome waste, especially because it can generate undesirable contaminants to the environment

- negligent and irresponsible sales of industrial waste with undeclared toxic contaminants for incineration in industrial furnaces may occur

- because of the dangers related to contamination of the cement produced from the use of industrial waste, its use should be avoided as much as possible in the absence of additional controls.

\section{REFERENCES}

[1] M. Achternbosch, K. R. Bräutigam, N. Hartlieb, C. Kupsch, U. Richers, P. Stemmermann, M. Gleis, Heavy metals in cement and concrete resulting from the co-incineration of wastes in cement kilns with regard to the legitimacy of waste utilization, Forschungszentrum Karlsruhe GmbH, Karlsruhe , 2003.

[2] R. Kikuchi, R. Gerardo, "More than a decade of conflict between hazardous waste management and public resistance: A case study of NIMBY syndrome in Souselas (Portugal)”, Journal of Hazardous Materials, Volume 172, No. 2-3, pp. 1681-1685, 2009

[3] L. P. C. Monteiro, Avaliação do Impacto Ambiental Associado à Queima de Resíduos Industriais em Fornos de Clínquer: visão sob o prisma da educação ambiental, Universidade Federal Fluminense, Tese de Doutorado, UFF, Outubro, 2007

[4] C. Y. Kawabata, H. Savastano Junior, J. Souza-Coutinho, "Rice husk derived waste materials as partial cement replacement in lightweight concrete”, Ciência e Agrotecnologia, Vol.. 36, No. 5, pp. 567-578, 2012

[5] J. G. Silva, Há emissões acrescidas na co-incineração de resíduos industriais perigosos em cimenteiras, Universidade de Coimbra, Associação Nacional de Conservação da Natureza, QUERCUS, 2002

[6] R. Ferrari, "Co-processamento de resíduos industriais em fornos de clínquer”, Companhia de Cimento Itambé, Balsa Nova, 2002

[7] P. Shih, J. Chang, H. Lu, L. Chiang, "Reuse of heavy metal-containing sludges in cement production", Cement and Concrete Research, Vol. 35, No. 11 , pp. 2110-2115, 2005

[8] D. Lemarchand, "Cement kiln incineration associated to pre-treatment, a viable waste management solution”, Congresso Brasileiro de Cimento, Anais São Paulo, 1999

[9] F. Bagnoli, A. Bianchi, A. Ceccarini, R. Fuoco, S. Giannarelli, "Trace metals and organic pollutants in treated and untreated residues from urban solid waste incinerators”, Microchemical Journal, Vol. 79, No. 12, pp. 291-297, 2005

[10] F. B. Mainier, B. P. Salvini, L. P. C. Monteiro , R. J. Mainier, "Recycling of tires in Brazil: a lucrative business or an imported problem", International Journal of Engineering and Applied Sciences, Vol. 2, No. 3, pp. 19-28, 2013 